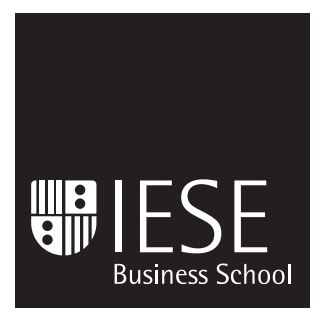

University of Navarra
Working Paper

WP No 657

October, 2006

\title{
THE EQUITY PREMIUM IN FINANCE AND VALUATION TEXTBOOKS
}

\author{
Pablo Fernández
}

IESE Business School - University of Navarra

Av. Pearson, 21 - 08034 Barcelona, Spain. Tel.: (+34) 932534200 Fax: (+34) 932534343

Camino del Cerro del Águila, 3 (Ctra. de Castilla, km 5,180) - 28023 Madrid, Spain. Tel.: (+34) 913570809 Fax: (+34) 913572913

Copyright ${ }^{\odot} 2006$ IESE Business School. 
The CIIF, International Center for Financial Research, is an interdisciplinary center with an international outlook and a focus on teaching and research in finance. It was created at the beginning of 1992 to channel the financial research interests of a multidisciplinary group of professors at IESE Business School and has established itself as a nucleus of study within the School's activities.

Ten years on, our chief objectives remain the same:

- Find answers to the questions that confront the owners and managers of finance companies and the financial directors of all kinds of companies in the performance of their duties

- Develop new tools for financial management

- Study in depth the changes that occur in the market and their effects on the financial dimension of business activity

All of these activities are programmed and carried out with the support of our sponsoring companies. Apart from providing vital financial assistance, our sponsors also help to define the Center's research projects, ensuring their practical relevance.

The companies in question, to which we reiterate our thanks, are:

Aena, A.T. Kearney, Caja Madrid, Fundación Ramón Areces, Grupo Endesa, Royal Bank of Scotland and Unión Fenosa.

http://www.iese.edu/ciif/ 


\title{
THE EQUITY PREMIUM IN FINANCE AND VALUATION TEXTBOOKS
}

\author{
Pablo Fernández*
}

\section{Abstract}

This paper is a revision of the recommendations about the equity premium found in the main finance and valuation textbooks. Herein, several editions of books written by authors such as, Brealey and Myers; Copeland, Koller and Murrin (McKinsey); Ross, Westerfield and Jaffe; Bodie, Kane and Marcus; Damodaran; Copeland and Weston; Van Horne; Bodie and Merton; Stowe et al.; Pratt; Penman; Bruner; Weston \& Brigham; and Arzac, are revised.

The aim is to highlight the confusing message of the textbooks regarding the equity premium and its evolution.

The main confusion arises from not distinguishing among the four concepts that the word equity premium designates: Historical equity premium (HEP), Expected equity premium, Required equity premium (REP) and Implied equity premium (IEP).

Some confusion also arises from not recognizing that although the HEP is equal for all investors, the REP, the EEP and the IEP are different for different investors. A unique IEP requires assuming homogeneous expectations for the expected growth (g), but there are several pairs (IEP, g) that satisfy current prices. We claim that different investors have different REPs and that it is impossible to determine the REP for the market as a whole, because it does not exist.

* Professor, Financial Management, PricewaterhouseCoopers Chair of Finance, IESE

JEL Classification: G12, G31, M21

Keywords: equity premium, equity premium puzzle, required market risk premium, historical market risk premium, expected market risk premium, risk premium, market risk premium, market premium. 


\section{THE EQUITY PREMIUM IN FINANCE AND VALUATION TEXTBOOKS}

\section{Introduction}

The equity premium (also called market risk premium, equity risk premium, market premium and risk premium), is one of the most important, discussed but elusive parameters in finance. Much of the confusion arises from the fact that the term equity premium is used to designate four different concepts:

1. Historical equity premium (HEP): historical differential return of the stock market over treasuries.

2. Expected equity premium (EEP): expected differential return of the stock market over treasuries.

3. Required equity premium (REP): incremental return of a diversified portfolio (the market) over the risk-free rate required by an investor. ${ }^{1}$ It is needed for calculating the required return to equity (cost of equity). The CAPM assumes that REP and EEP are unique and that REP $=$ EEP.

4. Implied equity premium (IEP): the required equity premium that arises from assuming that the market price is correct.

The four concepts are different. ${ }^{2}$ The HEP is easy to calculate and is equal for all investors, ${ }^{3}$ but the REP, the EEP and the IEP are different for different investors and are not observable magnitudes. A matter of big concern is the fact that, there is no an IEP for the market as a whole: different investors have different IEPs and use different REPs. ${ }^{4}$ A unique IEP requires

\footnotetext{
${ }^{1}$ Or the extra return that the overall stock market must provide over the Government Bonds to compensate for the extra risk.

${ }^{2}$ We agree with Bostock (2004) when he says that "understanding the equity premium is largely a matter of using clear terms".

${ }^{3}$ Provided they use the same time frame, the same market index, the same risk-free instrument and the same average (arithmetic or geometric).

${ }^{4}$ There is a required equity premium (REP) for each investor, but we cannot talk about a REP for the whole market. Similarly, for having a EEP common for al investors we need to assume homogeneous expectations and, with our knowledge of financial markets, this assumption is not reasonable.
} 
assuming homogeneous expectations for the expected growth (g), but there several pairs (IEP, g) that satisfy current prices.

The required equity premium (REP) is the answer to the following question: What incremental return do I require for investing in a diversified portfolio of shares (a stock index, for example) over the risk-free rate? It is a crucial parameter because the REP is the key to determining the company's required return to equity and the required return to any investment project.

An anecdote from Merton Miller (2000, page 3) about the expected market return in the Nobel context: "I still remember the teasing we financial economists, Harry Markowitz, William Sharpe, and I, had to put up with from the physicists and chemists in Stockholm when we conceded that the basic unit of our research, the expected rate of return, was not actually observable. I tried to tease back by reminding them of their neutrino - a particle with no mass whose presence was inferred only as a missing residual from the interactions of other particles. But that was eight years ago. In the meantime, the neutrino has been detected".

The historical equity premium is the historical average differential return of the market portfolio (usually a stock market index, such as the S\&P 500) over the risk-free debt. ${ }^{5}$ The most widely cited source is Ibbotson Associates whose U.S. database starts in 1926. Another frequently used source is the Center for Research in Security Prices (CRSP) at the University of Chicago. Table 1 contains the 1926-2005 average returns and HEP for the US according to Ibbotson Associates (2006), the most used source of historical data. ${ }^{6}$

\section{Table 1. Returns and HEP of the US according to Ibbotson Associates (2006).} 1926-2005

\begin{tabular}{|c|c|c|c|c|}
\hline \multirow[b]{2}{*}{ Nominal Returns 1926-2005 } & \multicolumn{2}{|c|}{ Average return } & \multirow{2}{*}{$\begin{array}{l}\text { Standard } \\
\text { deviation }\end{array}$} & \multirow{2}{*}{$\begin{array}{l}\text { Serial } \\
\text { correlation }\end{array}$} \\
\hline & Arithmetic & Geometric & & \\
\hline S\&P 500 & $12.3 \%$ & $10.4 \%$ & $20.2 \%$ & $3 \%$ \\
\hline Long-Term Gov. Bonds & $5.8 \%$ & $5.5 \%$ & $9.2 \%$ & $-8 \%$ \\
\hline T-Bills & $3.8 \%$ & $3.7 \%$ & $3.1 \%$ & $91 \%$ \\
\hline Inflation & $3.1 \%$ & $3.0 \%$ & $4.3 \%$ & $65 \%$ \\
\hline
\end{tabular}

\begin{tabular}{|l|r|r|}
\hline HEP over Gov. Bonds & $6.5 \%$ & $4.9 \%$ \\
\hline HEP over T-Bills & $8.5 \%$ & $6.7 \%$ \\
\hline
\end{tabular}

The IEP is the implicit REP used in the valuation of a stock (or market index) that matches the current market value. The most widely used model to calculate the IEP is the dividend discount model. According to it, the current price per share $\left(\mathrm{P}_{0}\right)$ is the present value of expected

\footnotetext{
${ }^{5}$ This difference can be calculated as an arithmetic average or geometric average. For the return of the risk-free debt, government bonds of different maturities may be used. A good discussion of the geometric and arithmetic average is Jacquier, Kane, and Marcus (2003).

${ }^{6}$ The HEP in Table 1 is the difference between the average return on the S\&P 500 and the return of Gov. Bonds or T-Bills. However, Ibbotson Associates (2006, page 73), use as return for the risk-free rate instrument the income return (the portion of the total return that results from a periodic bond coupon payment) of the Gov. Bonds (5.2\%) and consider that the relevant HEP during the period 1926-2005 is 7.1\% (12.3-5.2).
} 
dividends discounted at the required rate of return (Ke). If $d_{1}$ is the dividend per share ${ }^{7}$ expected to be received at time 1 , and g the expected long term growth rate in dividends per share,

$P_{0}=d_{1} /(K e-g)$, which implies: $K e=d_{1} / P_{0}+g . \quad$ IEP $=K e-R_{F}$

But even if market prices are correct for all investors, there is not a REP common for all investors: there are many pairs (Ke, g) and (IEP, g) that accomplish equation (1). If equation (1) holds, the expected return for the shareholders is equal to the required return for the shareholders (Ke), but there are many required returns (as many as expected growths, g) in the market. On top of that, IEP and g change over time.

We show that in the finance textbooks, there are authors that claim different identities among the four equity premiums defined above: ${ }^{8}$

- There are many authors that claim that HEP $=$ EEP $=$ REP.${ }^{9}$

- Authors that claim that EEP is smaller than HEP. ${ }^{10}$

- Authors that claim that there is a unique IEP and that REP $=$ IEP. ${ }^{11}$

- Authors that use a REP "for the sake of continuity with the previous version of the book"."12

- Authors that "have no official position".13

- Authors that claim "that no one knows what the REP is".14

- Authors that claim that "it is impossible to determine the REP for the market as a whole, because it does not exist". ${ }^{15}$

- Authors that claim that "different investors have different REPs"."16

Section 2 is a revision of the advice of the main finance textbooks about the risk premium. Section 3 shows that here is no a REP for the market as a whole and that the markets cannot be characterized by a representative consumer. Section 4 explains which REP I use. Section 5 concludes.

\footnotetext{
${ }^{7}$ That is for a company that pays to its shareholders only dividends. But if the company makes other payments to the equity holders (i.e. share repurchases), then the total equity cash flow per share should be considered.

${ }^{8}$ Fernandez (2006) revises also academic papers.

${ }^{9}$ For example: Brealey and Myers (1984, 1988, 1991, 1996); Copeland et al. (1990, 1995); Ross, Westerfield and Jaffe (1988, 1993, 1996, 1999, 2002, 2005); Stowe et al. (2002); Pratt (2002); Bruner (2004); Weston, Mitchel and Mulherin (2004); Bodie, Kane and Marcus (2003); Damodaran (1994, 2002, 2006); Ibbotson Associates (2006).

${ }^{10}$ For example: Copeland et al. $(2000$, REP $=$ EEP $=$ HEP-1.5-2\%); Goedhart et al. $(2005$, REP $=$ EEP $=$ HEP-1-2\%); Bodie, Kane and Marcus (1996, REP = EEP = HEP-1\%).

${ }^{11}$ For example: Damodaran (2001a); Arzac (2005); Goedhart, Koller and Wessels (2002);

${ }^{12}$ Damodaran (2001c), who adds: “and for purposes of saving a significant amount of reworking practice problems and solutions".

${ }^{13}$ For example: Brealey and Myers (2000, 2003, 2005).

${ }^{14}$ For example: Penman (2003).

${ }^{15}$ For example: Fernandez (2002).

${ }^{16}$ For example: Fernandez (2004).
} 


\section{The equity premium in the textbooks}

Figure 1 collects the evolution of the Required Equity Premium (REP) used or recommended by the books. Looking at Figure 1 is easy to understand the confusion that students and practitioners (and finance authors, also) have about the Equity Premium.

Table 2 contains the main conclusions about the Equity Premium in different editions of the books that we review in this section.

The following sections contain the main messages about the equity premium conveyed in the finance textbooks and valuation books.

Figure 1. Evolution of the Required Equity Premium (REP) used or recommended in the most important finance textbooks

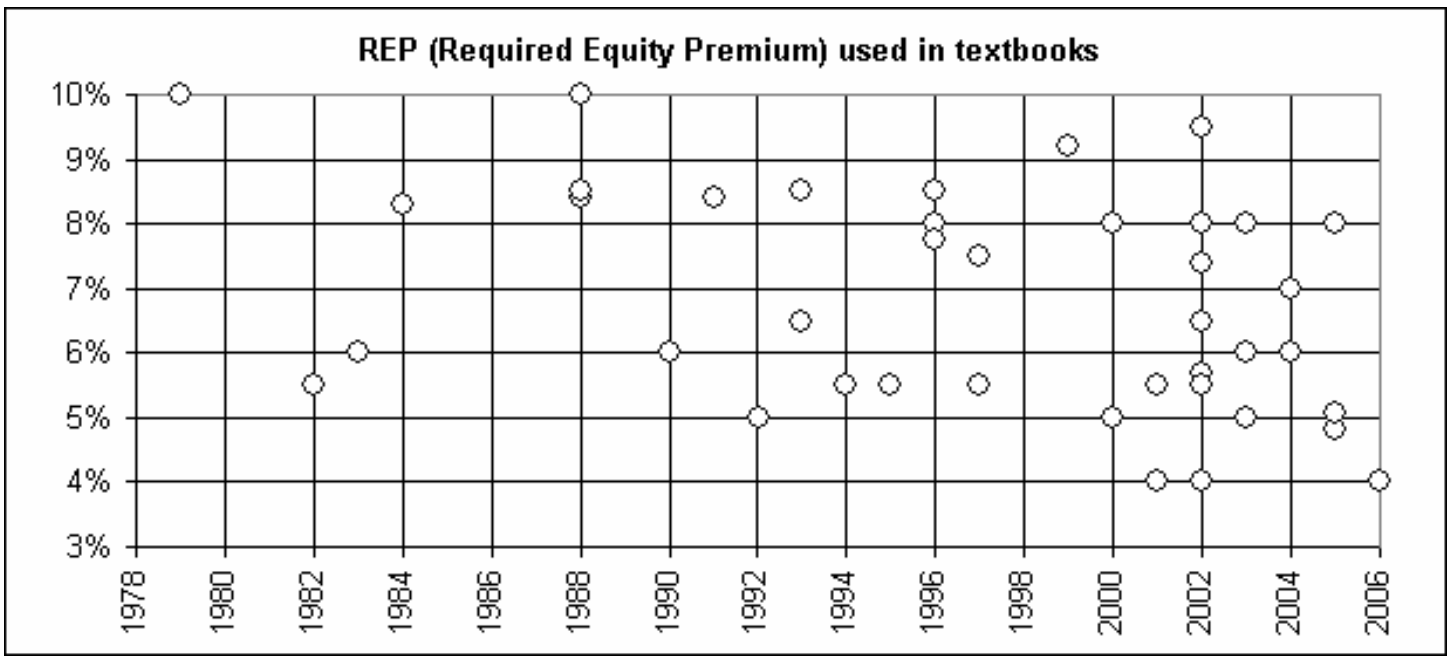

Table 2. Equity premiums recommended and used in textbooks

\begin{tabular}{|c|c|c|c|c|}
\hline Author(s) of the Textbook & Assumption & Period for HEP & $\begin{array}{c}\text { REP } \\
\text { recommended }\end{array}$ & REP used \\
\hline \multicolumn{5}{|l|}{ Brealey and Myers } \\
\hline 2nd edition. 1984 & $\mathrm{REP}=\mathrm{EEP}=$ arith HEP vs. T-Bills & $1926-81$ & $8.3 \%$ & $8.3 \%$ \\
\hline 3rd edition. 1988 & $\mathrm{REP}=\mathrm{EEP}=$ arith HEP vs. T-Bills & $1926-85$ & $8.4 \%$ & $8.4 \%$ \\
\hline 4th edition. 1991 & $\mathrm{REP}=\mathrm{EEP}=$ arith HEP vs. T-Bills & $1926-88$ & $8.4 \%$ & $8.4 \%$ \\
\hline 5th edition. 1996 & $\mathrm{REP}=\mathrm{EEP}=$ arith HEP vs. T-Bills & & $8.2-8.5 \%$ & \\
\hline $\begin{array}{l}6^{\text {th }} \text { and } 7^{\text {th }} \text { edition. } 2000 \text { and } \\
2003\end{array}$ & No official position & & $6-8.5 \%$ & $8 \%$ \\
\hline $8^{\text {th }}$ edition. 2005 (with Allen) & No official position & & $5-8.5 \%$ & \\
\hline \multicolumn{5}{|l|}{$\begin{array}{l}\text { Copeland, Koller and Murrin } \\
\text { (McKinsey) }\end{array}$} \\
\hline $1^{\text {st }}$ edition. 1990 & $\mathrm{REP}=\mathrm{EEP}=$ geo HEP vs. $\mathrm{T}$-Bonds & $1926-88$ & $5-6 \%$ & $6 \%$ \\
\hline $2^{\text {nd }}$ edition. 1995 & $\mathrm{REP}=\mathrm{EEP}=$ geo HEP vs. T-Bonds & 1926-92 & $5-6 \%$ & $5.5 \%$ \\
\hline $3^{\text {rd }}$ edition. 2000 & $\mathrm{REP}=\mathrm{EEP}=$ arith $\mathrm{HEP}-1.5-2 \%$ & $1926-98$ & $4.5-5 \%$ & $5 \%$ \\
\hline $\begin{array}{l}4^{\text {th }} \text { edition. 2005. Goedhart, } \\
\text { Koller \& Wessels }\end{array}$ & $\mathrm{REP}=\mathrm{EEP}=$ arith $\mathrm{HEP}-1-2 \%$ & 1903-02 & $3.5-4.5 \%$ & $4.8 \%$ \\
\hline
\end{tabular}




\begin{tabular}{|c|c|c|c|c|}
\hline \multicolumn{5}{|l|}{ Ross, Westerfield and Jaffe } \\
\hline $2^{\text {nd }}$ edition. 1988 & $\mathrm{REP}=\mathrm{EEP}=$ arith HEP vs. T-Bills & 1926-88 & $8.5 \%$ & $8.5 \%$ \\
\hline $3^{\text {rd }}$ edition. 1993 & $\mathrm{REP}=\mathrm{EEP}=$ arith HEP vs. T-Bills & 1926-93 & $8.5 \%$ & $8.5 \%$ \\
\hline $4^{\text {th }}$ edition. 1996 & $\mathrm{REP}=\mathrm{EEP}=$ arith HEP vs. T-Bills & 1926-94 & $8.5 \%$ & $8.5 \%$ \\
\hline $5^{\text {th }}$ edition. 1999 & $\mathrm{REP}=\mathrm{EEP}=$ arith HEP vs. T-Bills & 1926-97 & $9.2 \%$ & $9.2 \%$ \\
\hline $6^{\text {th }}$ edition. 2002 & REP $=E E P=$ arith HEP vs. T-Bills & 1926-99 & $9.5 \%$ & $9.5 \%$ \\
\hline $7^{\text {th }}$ edition. 2005 & $\mathrm{REP}=\mathrm{EEP}=$ arith HEP vs. $\mathrm{T}$-Bills & 1926-02 & $8.4 \%$ & $8 \%$ \\
\hline Van Horne, $6^{\text {th }}$ edition. 1983 & & & & $6 \%$ \\
\hline $8^{\text {th }}$ edition. 1992 & & & $3-7 \%$ & $5 \%$ \\
\hline Copeland and Weston (1979) & & & & $10 \%$ \\
\hline Copeland and Weston (1988) & & & & $10 \%$ \\
\hline Weston and Copeland (1992) & & & & $5 \%$ \\
\hline \multicolumn{5}{|l|}{ Bodie, Kane and Marcus } \\
\hline $2^{\text {nd }}$ edition. 1993 & $\mathrm{REP}=\mathrm{EEP}$ & & $6.5 \%$ & $6.5 \%$ \\
\hline $3^{\text {rd }}$ edition. 1996 & REP=EEP=arith HEP vs. T-Bills $-1 \%$ & & $7.75 \%$ & $7.75 \%$ \\
\hline $5^{\text {th }}$ edition. 2002 & & & $6.5 \%$ & $6.5 \%$ \\
\hline 2003 & $\mathrm{REP}=\mathrm{EEP}=$ arith HEP vs. T-Bills & 1926-01 & & $5 \% ; 8 \%$ \\
\hline $\begin{array}{l}\text { Damodaran } 1994 \text { Valuation. } \\
1^{\text {st }} \text { edition }\end{array}$ & $\mathrm{REP}=\mathrm{EEP}=$ geo HEP vs.T-Bonds & $1926-90$ & $5.5 \%$ & $5.5 \%$ \\
\hline $1996,1997,2001 b, 2001 c$ & $\mathrm{REP}=\mathrm{EEP}=$ geo HEP vs. $\mathrm{T}$-Bonds & & $5.5 \%$ & $5.5 \%$ \\
\hline $2001 a$ & average IEP & $1970-00$ & $4 \%$ & $4 \%$ \\
\hline 2002 & $\mathrm{REP}=\mathrm{EEP}=$ geo HEP vs. $\mathrm{T}$-Bonds & $1928-00$ & $5.51 \%$ & $5.51 \%$ \\
\hline 2006 Valuation. $2^{\text {nd }}$ edition & REP $=E E P=$ geo HEP vs. $T$-Bonds & 1928-04 & $4.84 \%$ & $4 \%$ \\
\hline Weston \& Brigham (1982) & & & $5-6 \%$ & \\
\hline $\begin{array}{l}\text { Weston, Chung and Siu } \\
\text { (1997) }\end{array}$ & & & $7.5 \%$ & \\
\hline Bodie and Merton (2000) & & & & $8 \%$ \\
\hline Stowe et al. (2002) & $\mathrm{REP}=\mathrm{EEP}=$ geo HEP vs. T-Bonds & $1926-00$ & $5.7 \%$ & $5.7 \%$ \\
\hline Hawawini and Viallet (2002) & $\mathrm{REP}=\mathrm{EEP}=$ geo HEP vs. T-Bonds & 1926-99 & & $6.2 \%$ \\
\hline Pratt (2002) & $\mathrm{REP}=\mathrm{EEP}=\mathrm{HEP}$ & & & $7.4 \%, 8 \%$ \\
\hline Fernandez (2002) & "is impossible to determine the premium & e market & ole" & \\
\hline Penman (2003) & "No one knows what the REP is" & & & $6 \%$ \\
\hline Fernandez $(2001,2004)$ & "different investors have different REPs" & & & $4 \%$ \\
\hline Bruner (2004) & $\mathrm{REP}=\mathrm{EEP}=$ geo HEP vs. T-Bonds & $1926-00$ & $6 \%$ & $6 \%$ \\
\hline $\begin{array}{l}\text { Weston, Mitchel \& Mulherin } \\
\text { (2004) }\end{array}$ & $\mathrm{REP}=\mathrm{EEP}=$ arith HEP vs.T-Bonds & $1926-00$ & $7.3 \%$ & $7 \%$ \\
\hline Arzac (2005) & $R E P=I E P$ & & $5.08 \%$ & $5.08 \%$ \\
\hline
\end{tabular}

\subsection{Brealey and Myers}

Brealey and Myers maintained that REP $=$ EEP $=$ HEP in their books until the $4^{\text {th }}$ edition. After that, they recognized that "Brealey and Myers have no official position on the exact market risk premium". 
In $\left(1984,2^{\text {nd }}\right.$ edition, pages 119,132$)$ they used REP $=$ EEP $=$ HEP $=8.3 \%$, the arithmetic HEP over T-Bills in the period 1926-1981 according to Ibbotson. ${ }^{17}$

In $\left(1988,3^{\text {rd }}\right.$ edition, pages $\left.126,139,140,185\right)$, they used $\operatorname{REP}=\mathrm{EEP}=\mathrm{HEP}=8.4 \%$, the arithmetic HEP over T-Bills in the period 1926-1985 according to Ibbotson.

In $\left(1991,4^{\text {th }}\right.$ edition, page 131), they focused on the arithmetic HEP over T-Bills in the period 1926-1988, which was 8.4\%. They continued considering that REP $=$ EEP $=$ HEP and used 8.4\% in their examples (pages 131, 194, 196).

In (1996, $5^{\text {th }}$ edition), they suggested 8.2-8.5\%.

In $\left(2000,6^{\text {th }}\right.$ edition, page 160), they recognized that "Brealey and Myers have no official position on the exact market risk premium, but we believe a range of 6 to $8.5 \%$ is reasonable for the United States. We are most comfortable with figures toward the upper end of the range". Further on, on page 195, they say: "How about the market risk premium? From past evidence it appears to be 8 to 9\%, ${ }^{18}$ although many economists and financial managers would forecast a lower figure". They also mentioned that "Many financial managers and economists believe that long-run historical returns are the best measure available".

In $\left(2003,7^{\text {th }}\right.$ edition, page 160$)$, they continued without official position, and believing in the range of 6 to 8.5\%. On page 195, they said: "How about the market risk premium? As we have pointed out in the last chapter, we can't measure EEP with precision. From past evidence it appears to be about 9\%, ${ }^{19}$ although many economists and financial managers would forecast a lower figure. Let's use $8 \%$ in this example".

Brealey, Myers and Allen (2005), on page 154 of the $8^{\text {th }}$ edition say "Brealey, Myers and Allen have no official position on the exact market risk premium, but we believe that a range of 5 to 8.5 percent is reasonable for the risk premium in the United States". ${ }^{20}$

\subsection{Copeland, Koller and Murrin (McKinsey)}

In the two first editions (1990 and 1995), the McKinsey book advised to use a REP = geometric HEP versus Government T-Bonds. However, they changed criteria in the $3^{\text {rd }}$ and $4^{\text {th }}$ editions: they advised to use the arithmetic HEP of 2-year returns versus Government T-Bonds reduced by a survivorship bias. Although in the $2^{\text {nd }}$ edition they said that (page 268) "we use a geometric average of rates of return because arithmetic averages are biased by the measurement period", they used arithmetic averages in the $3^{\text {rd }}$ and $4^{\text {th }}$ editions.

\footnotetext{
${ }^{17}$ They said on pages 119 of (1984), 127 of (1988) and 131 of (1991) that "the crucial assumption here is that there is a normal, stable risk premium on the market portfolio, so that the expected future risk premium can be measured by the average past risk premium. One could quarrel with this assumption, but at least it yields estimates of the market return that seem sensible."

${ }^{18}$ They reported on page 156 the arithmetic HEP versus the T-Bills in the period 1926-1997 (9.2\%).

${ }^{19}$ They reported on page 155 the arithmetic HEP versus the T-Bills in the period 1926-2000 according to Ibbotson (9.1\%).

20 "It seems that the expected market return over this period was 9.4\%, or 5.3\% above the risk-free interest rate. This is 2.3\% lower than the realized risk premium in the period 1900-2003." The average market return that they used was (page 149) 11.7\% (figures from Dimson, Marsh and Staunton).
} 
In the $1^{\text {st }}$ edition (1990), they recommended 5-6\% (page 193) and used a REP of 6\% (page 205) because (see page 196): "Our opinion is that the best forecast of the risk premium is its longrun geometric average”. ${ }^{21}$

In the $2^{\text {nd }}$ edition (1995) they recommended 5-6\% (page 268) ${ }^{22}$ and used a REP of 5.5\% (page 281).

In the $3^{\text {rd }}$ edition (2000, page 221), they recommended 4.5-5\% (page 221) and used a REP of 5\% (page 231). They justify their recommendation as follows: "It is unlikely that the U.S. Market index will do as well over the next century as it has in the past, so we adjust downward the historical arithmetic average market risk premium. If we subtract a 1.5 to $2 \%$ survivorship bias $^{23}$ from the long-term arithmetic average of 6.5\%, we conclude that the market risk premium should be in the $4.5-5 \%{ }^{24}$ range".

In the $4^{\text {th }}$ edition of the McKinsey valuation book, Koller, Goedhart and Wessels (2005, page 297) state that the REP is equal to the EEP and say on page 298: "we believe that the market risk premium as of year-end 2003 was just under 5\%". On page 539 they use in an example a REP of 4.8\%. On page 303, they argue that "Since it is unlikely that the U.S. stock market index will replicate its performance over the next century, we adjust downward the historical arithmetic average market risk premium. Using data from Jorion and Goetzmann, we find that between 1926 and 1996, the U.S. arithmetic annual return exceeded the median return on a set of 11 countries with continuous histories dating to the 1920 s by 1.9\% in real terms, or $1.4 \%$ in nominal terms. If we subtract a $1 \%$ to $2 \%$ survivorship bias from the long-term arithmetic average of 5.5 percent, ${ }^{25}$ the difference implies the future range of the US market risk premium should be $3.5 \%$ to $4.5 \%$.

\subsection{Ross, Westerfield and Jaffe}

In all editions they recommend REP $=$ EEP $=$ arithmetic HEP vs. T-Bills, using Ibbotson data.

In (1988, $2^{\text {nd }}$ edition), they considered (pages 243-4) that REP $=$ EEP $=$ arithmetic HEP versus T-Bills for $1926-1988=8.5 \%(12.1 \%-3.6 \%)$ and used it on page 287 .

In (1993, $3^{\text {rd }}$ edition), they also recommended 8.5\%.

In (1996, $4^{\text {th }}$ edition), they considered (page 241) that REP $=$ EEP $=$ arithmetic HEP versus T-Bills for $1926-1994=8.5 \%(12.2 \%-3.7 \%)$ and used it on page 280 .

\footnotetext{
${ }^{21}$ They report on page 194 the geometric HEP versus the T-Bonds in the period 1926-1988 according to Ibbotson (5.4\%).

${ }^{22}$ Copeland, Koller and Murrin (1995, $2^{\text {nd }}$ ed., page 268): “We recommend using a 5 to 6\% market risk premium for US companies. This is based on the long-run geometric average risk premium for the return of the S\&P 500 versus the return on long-term government bonds from 1926 to 1992 ".

${ }^{23}$ They refer to two papers about survivorship bias: Brown, Goetzmann and Ross (1995) and Jorion and Goetzmann (1999). Survivorship biaswas identified by Brown, Goetzmann and Ross (1995) as one of the main reasons why the results based on historical analyses can be too optimistic. They pointed out that the observed return, conditioned on survival (HEP), can overstate the unconditional expected return (EEP). However, $\mathrm{Li}$ and $\mathrm{Xu}$ (2002) show that the "survival bias" fails to explain the equity premium puzzle: "To have high survival bias, the probability of market survival over the long run has to be extremely small, which seems to be inconsistent with existing historical evidence".

${ }^{24} 6.5 \%$ is the arithmetic HEP of 2-year returns in the period 1926-1998 (see page 220). The arithmetic HEP of 1-year returns was 7.5\%, and the geometric HEP was 5.9\%.

${ }^{25} 5.5 \%$ is the arithmetic mean of 10-year holding periods returns from 1903 to 2002. The arithmetic mean of 1-year returns is 6.2\%, according to exhibit 10.5 of Koller, Goedhart and Wessels (2005).
} 
In $\left(1999,5^{\text {th }}\right.$ edition), they considered (page 259) that REP $=$ EEP $=$ arithmetic HEP versus T-Bills for 1926-1997 $=9.2 \%(13 \%-3.8 \%)$ and used it on page 261 . They argued that "It is generally argued that the best estimate for the risk premium in the future is the average risk premium in the past".

In $\left(2002,6^{\text {th }}\right.$ edition), they considered (page 259) that REP $=$ EEP $=$ arithmetic HEP versus T-Bills for 1926-1999 $=9.5 \%(13.3 \%-3.8 \%)$ and used it on pages 274 and 324 . They mentioned (1999 in page 259; 2002 in page 273) that "financial economists use [the HEP] as the best estimate to occur in the future. We will use it frequently in the text".

In $\left(2005,7^{\text {th }}\right.$ edition), they considered (page 259) that REP $=$ EEP $=$ arithmetic HEP versus T-Bills for $1926-2002=8.4 \%(12.2 \%-3.8 \%)$ because "financial economists find this to be a useful estimate of the difference to occur in the future". ${ }^{26}$ However, on page 286 they used a REP $=8 \%$.

\subsection{Bodie, Kane and Marcus}

In $\left(1993,2^{\text {nd }}\right.$ edition, page 549), they used a REP $=\mathrm{EEP}=6.5 \%(14.5 \%-8 \%)$ to value HewlettPackard. They justified it by saying "Suppose the consensus forecast for the expected rate of return on the market portfolio in 1990 was about $14.5 \%{ }^{27}$

In the $3^{\text {rd }}$ edition (1996, page 535), they used a REP $=$ EEP $=$ HEP $-1 \%=7.75 \%$ to value Motorola. ${ }^{28}$

In the $5^{\text {th }}$ edition (2002, page 575), they valued Motorola using a REP $=6.5 \%(12.5 \%-6 \%){ }^{29}$

In the $6^{\text {th }}$ edition (2003), they used CRSP data to calculate the arithmetic HEP vs. T-bills for 1926-2001, which was 8.64\% (12.49\%-3.85\%). They said on page 157 that "the instability of average excess return over the 19-year sub-periods calls into question the precision of the 76-year average HEP (8.64\%) as an estimate of the EEP... There is an emerging consensus that the HEP is an unrealistic high estimate of the EEP". They used in the examples different REPs: $8 \%$ (pages 426, 431) and 5\% (page 415).

\subsection{Damodaran}

In 1994 and 2002 Damodaran recommended REP = EEP = geometric HEP versus T-bonds. In 1997 he used a REP = arithmetic HEP versus T-Bills. In 2001a and 2006 he recommended REP = $\mathrm{EEP}=\mathrm{IEP}$.

\footnotetext{
${ }^{26}$ But they finish with a caveat on page 284: "of course, the future equity risk premium could be higher or lower than the historical equity risk premium. This could be true if future risk is higher or lower than past risk or if individual risk aversions are higher or lower than those of the past".

${ }^{27}$ It is not clear how they got the 14.5\%. They presented (pages 126 and 127) CRSP historical data for 1926-1990. The average arithmetic returns were: 12.13\% for stocks, 4.9\% for T-Bonds and 3.73\% for T-Bills.

${ }^{28}$ They argue that "the HEP has been closer to 8.5\%. However, stock analysts were relatively pessimistic about market performance over the short term. Although the HEP is a guide to the EEP one might expect from the market, there is no reason that the risk premium cannot vary somewhat from period to period". The 8.5\% that they mentioned was the arithmetic HEP using T-Bills in the period 1926-1993.

${ }^{29}$ They argue that "the HEP has been closer to 9.14\%. However, after several banner years, stock analysts in mid2000 were increasingly wary about future market performance over the short term. Although the HEP is one guide as to the EEP one might expect from the market, there is no reason that the risk premium cannot vary somewhat from period to period. Moreover, recent research suggests that in the last 50 years the HEP was considerably better then the market participants at the time were anticipating. Such a pattern could indicate that the economy performed better than initially anticipated during this period, or that the discount rate declined". The 9.14\% that they mentioned was the arithmetic HEP using T-Bonds in the period 1926-1999.
} 
Damodaran on Valuation (1994, page 22), recommended an EEP of 5.5\%, the HEP (geometric mean using T-bonds) for the period 1926-1990: "The premium of 5.50\% is used through the book for calculating expected returns". However, on page 24, he calculated the cost of equity of Pepsico using a REP of 6.41\% (geometric HEP 1926-1990 using T-Bills). For Germany (page 164) he used a REP of 3.3\%.

Damodaran on Valuation (2006, $2^{\text {nd }}$ edition) used a REP of $4 \%$ for the US. He said that the most relevant historical figure is the geometric HEP versus T-Bonds, that for the period 1928-2004, was $4.84 \%$. He used a dividend discount model to conclude that "the implied premium for the US and the average implied equity risk premium has been between about 4\% over the past 40 years".

Damodaran (2001a, page 63) recommended “6.05\%, which is the geometric average premium for stocks over treasury bonds from 1928 to 1999 if you use historical premiums. In using this premium, however, you are assuming that there are no trends in the risk premium and that investors today demand premiums similar to those they used to demand two, four, or six decades ago. Given the changes that have occurred in the markets and in the investor base over the last century, you should have serious concerns about using this premium, especially in the context of valuation". But Damodaran (2001a, page 67) concluded: "The average implied equityrisk premium between 1970 and 2000 is approximately 4\%. By using this premium, you are assuming that while markets might have been overvalued in some of these years and undervalued in others, it has been, on average, correct over this period". Throughout his book, Damodaran (2001a) used a REP $=4 \%$ for the U.S.

Damodaran (2001b), however, used a REP of 5.5\% (see, for example, pages 237, 339, 425 and 426). On the first edition (1997), he already used a REP of 5.5\% for the US in most of the examples, but on page 128 he calculated the cost of equity of Pepsico using a REP of 8.41\% (arithmetic HEP 1926-1990 using T-Bills).

Damodaran (2001c) mentioned (page 192) that although the geometric HEP versus T-bonds from Ibbotson for 1926-1998 (6.38\%), "in this book we use a premium of 5.5\% in most of the examples involving US companies". But he continued in a footnote "we must confess that this is more for the sake of continuity with the previous version of the book and for purposes of saving a significant amount of reworking practice problems and solutions".

Damodaran (Investment Valuation, 2002, pages 170, 171) used a REP $=$ HEP $=5.51 \%$ for US, which is the geometric HEP versus T-bonds in the period 1928-2000 according to the Federal Reserve Bank. On page 174 he argued that "the market correction in 2000 pushed the implied equity premium up to $2.87 \%$ by the end of 2000" and suggested an equation for the implied equity premium between 1960 and 2000:

$$
\text { Implied equity premium }=1.87 \%+0.2903 \text { (T-bond rate })-0.1162(\mathrm{~T}-\text { bond }-\mathrm{T} \text {-bill }) .{ }^{30}
$$

In the first edition (1996), he used (page 251) a REP of 5.5\% to value Boeing. On page 48, he shows that 5.5\% is the geometric HEP versus T-bonds in the period 1926-1990.

\footnotetext{
${ }^{30}$ Damodaran provides the R-squared of the regression (49\%) and the t-statistics of the coefficients (5.94 and 1.10 respectively).
} 


\subsection{Copeland and Weston}

In (1979, page 295), they used a REP $=10 \%$ (17\%-7\%), and on page 321 they used 9.83\%. In their $3^{\text {rd }}$ edition (1988) they used the same values (see pages 458 and 531).

Weston and Copeland (1992, page 407), used a REP $=5 \%$ (9\%-4\%), and on page 944 a REP $=$ $5 \%(11 \%-6 \%)$.

\subsection{Van Horne}

In $\left(1968,1^{\text {st }}\right.$ edition, page 215$)$, he still did not mention the CAPM or the market risk premium.

In $\left(1983,6^{\text {th }}\right.$ ed.ition, page 215$)$, he used a REP $=6 \%(13 \%-7 \%)$. He justified it: "Suppose, for easy illustration, that the expected risk-free rate is an average of the risk-free rates that prevailed over the ten-year period and that the expected market return is average of market returns over that period".

In (1986, page 373), he mentioned that "for the expected return of the market portfolio of stocks, one can use consensus estimates of security analysts, economists, and others who regularly predict such returns. Merrill, Lynch and other investment banks make these predictions".

In (1992, Fundamentals, $8^{\text {th }}$ ed., page 438$)$, he used a REP $=5 \%(13 \%-8 \%)$. He justified it: "Assume that a rate of return of about 13\% on stocks in general is expected to prevail and that a risk-free rate of $8 \%$ is expected". He added: "the "before hand' or ex ante market risk premium has ranged from 3 to $7 \%$ ".

\subsection{Penman}

In (2001, $1^{\text {st }}$ ed.ition, page 692), he said that "the market risk premium is a big guess. Research papers and textbooks estimate it in the range of 4.5\% to 9.2\%. Pundits keen to rationalize the 'high' stock market at the end of the 1990s were brave enough to state that it had declined to $2 \%$... Compound the error in beta and the error in the risk premium and you have a considerable problem... No one knows what the market risk premium is".

In (2003, $2^{\text {nd }}$ ed., page 445), he admitted that "we really do not have a sound method to estimate the cost of capital... Estimates [of the equity premium] range, in texts and academic research, from 3.0\% to 9.2\%", and he used 6\% (page 443).

\subsection{Other finance textbooks and valuation books}

Weston and Brigham (1968) still did not defined equity premium, but they defined the cost of equity (page 189) as "the minimum rate of return that must be earned to keep unchanged the value of the existing common equity". In $\left(1982,6^{\text {th }}\right.$ edition, page 393$)$ they said that "the market risk premium can be considered relatively stable at 5 to $6 \%$ for practical application". 
Weston, Chung and Siu (1997) recommend 7.5\%.

Bodie and Merton (2000) use $8 \%$ for USA. ${ }^{31}$

Stowe, Robinson, Pinto and McLeavey (2002), in their book for the CFA (Chartered Financial Analysts) Program use (page 49) a REP = Geometric HEP using T-Bonds during 1926-2000, according to Ibbotson $=5.7 \% .^{32}$

Pratt (2002) affirms that "Cost of capital is the expected rate of return that the market requires in order to attract funds to a particular investment". He assumes that REP = EEP = HEP and he uses 7.4\% (page 68) and 8\% (page 74) and 8.10\%.

Hawawini and Viallet (2002) use (page 328) a REP $=6.2 \%=$ geometric HEP over T-bonds in the period 1926-1999 according to Ibbotson.

Fernandez (2002) is the only finance textbook that claims that "it is impossible to determine the premium for the market as a whole, because it does not exist. Even if we knew the market premiums of the different investors who operated on the market, it would be meaningless to talk of a premium for the market as a whole". He also mentions that we "could only talk of a market risk premium if all investors had the same cash flow expectations". "If they did, it would make sense to talk of a market risk premium because all investors would have the market portfolio. However, expectations are not homogeneous".

Fernandez $(2004,2001)$ also mentioned that "the HEP, the EEP and the REP are different concepts" and that "different investors have different REPs". In the examples (see pages 608 and 623) he uses REP $=4 \%$.

Weston, Mitchel and Mulherin (2004) mention that the arithmetic HEP over T-bonds in the period 1926-2000 according to Ibbotson was 7.3\%, while the geometric was 5.7\%. In page 260 they use REP $=\mathrm{EEP}=7 \%$.

Bruner (2004, pages 269 and 294) uses a required equity premium of 6\% because (see page 265) "from 1926 to 2000, the risk premium for common stocks has averaged about 6\% when measured geometrically".

Arzac (2005) uses (see exhibit 3.4) a required equity premium of 5.08\% for a valuation done in December 2002 (5.08\% is the expected equity premium as of that date calculated using the Gordon equation).

\footnotetext{
${ }^{31}$ On page 347, they say that "in the CAPM, the equilibrium risk premium on the market portfolio is equal to the variance of the market portfolio $\left(\sigma_{M}^{2}\right)$ times a weighted average of the degree of risk aversion of the holders of wealth (A). Suppose that $\sigma_{M}=20 \%$ and $A=2$. Then the risk premium on the market portfolio is $8 \%$." The CAPM tells us that asset prices are a function of the risk aversion of the representative investor and of the variancecovariance structure of the universe of assets. If the form of the utility function and the coefficient of risk aversion are both known, then knowledge of the variance-covariance of the universe of assets (or the variance of the portfolio of risky assets) is sufficient to identify the spread between risky and riskless asset portfolios.

32 They also mention another method to calculate the cost of equity: the "bond yield plus risk premium method". Under this approach, the cost of equity is equal to the "yield to maturity on the company's long-term debt plus a typical risk premium of $3-4 \%$, based on experience."
} 


\begin{tabular}{|l|l|l|}
\cline { 2 - 3 } \multicolumn{1}{l|}{ REP $=$ HEP } & vs. T-Bills & vs. T-Bonds \\
\hline Arithmetic & $\begin{array}{l}\text { Brealey and Myers (1984, 1988, 1991, } \\
\text { 1996) } \\
\text { Ross, Westerfield and Jaffe (1988, 1993, } \\
1996,1999,2002,2005) ; \text { Bodie, Kane } \\
\text { and Marcus (2003); Pratt (2002) }\end{array}$ & Weston, Mitchel \& Mulherin (2004) \\
\hline Arithmetic - survivor bias & & $\begin{array}{l}\text { McKinsey (2000, 2005); Bodie, Kane } \\
\text { and Marcus (1996) }\end{array}$ \\
\hline Geometric & & $\begin{array}{l}\text { McKinsey (1990, 1995); Damodaran } \\
\text { (1994, 1996, 1997, 2001b, 2001c, } \\
\text { 2002, 2006); Stowe et al. (2002); } \\
\text { Hawawini and Viallet (2002); Bruner } \\
\text { (2004) }\end{array}$ \\
\hline
\end{tabular}

\begin{tabular}{|l|l|}
\hline REP = IEP & Damodaran (2001a); Arzac (2005) \\
\hline "No oficial position" & Brealey and Myers (2000, 2003, 2005) \\
\hline "Different investors have different REPs" & Fernandez (2001, 2002, 2004) \\
\hline "No one knows what the REP is" & Penman (2003) \\
\hline
\end{tabular}

\section{There is no a REP for the market as a whole}

We claim that the confusion about the Equity Premium comes from the fact that there is not a REP for the market as a whole: different investors use different REP. The same could be said about IEP: different investors have different IEPs. A unique IEP requires assuming homogeneous expectations for the expected growth (g), but there are several pairs (IEP, g) that satisfy current prices.

Similarly, for having an EEP common for all investors we need to assume homogeneous expectations (or a representative investor) and, with our knowledge of financial markets, this assumption is not reasonable. A theory with a representative investor cannot explain either why the annual trading volume of most exchanges more than double the market capitalization.

We can find out an investor's REP by asking him, although for many investors the REP is not an explicit parameter but, rather, an implicit one that manifests in the price they are prepared to pay for shares. However, it is impossible to determine the REP for the market as a whole, because it does not exist. Even if we knew the REPs of all the investors in the market, it would be meaningless to talk of a REP for the market as a whole.

The rationale for this is to be found in the aggregation theorems of microeconomics, which in actual fact are non-aggregation theorems. One model that works well individually for a number of people may not work for all of the people together. ${ }^{33}$

\footnotetext{
${ }^{33}$ As Mas-Colell et al. (1995, page 120) say, "it is not true that whenever aggregate demand can be generated by a representative consumer, this representative consumer's preferences have normative contents. It may even be the case that a positive representative consumer exists but that there is no social welfare function that leads to a normative representative consumer." For the CAPM, this means that although the CAPM may be a valid model for each investor, it is not valid for the market as a whole, because investors do not have the same return and risk expectations for all shares. Prices are a statement of expected cash flows discounted at a rate that includes the risk premium. Different investors have different cash flow expectations and different future risk expectations. One could only talk of a equity premium if all investors had the same cash flow expectations.
} 


\section{How do I calculate the REP?}

For calculating the cost of equity (required return to equity cash flows) of a company, a valuator has to answer to the following question: which differential rate over current T-Bond yields do I think that compensates the risk of holding the shares? If there is only an owner of the shares, we can ask him directly the question. But if it is a traded company, the valuator has to do a prudential judgment.

We need the cost of equity to discount the expected equity cash flows of the company. Note that there is a kind of schizophrenic approach to valuation: while all authors admit that different valuators and investors may have different expectations of equity cash flows, most authors look for a unique discount rate. It seems as if the expectations of equity cash flows are formed in a democratic regime, while the discount rate is determined in a dictatorship. In any market, different investors may have different expectations of equity cash flows and different evaluations of its risk (that translate into different discount rates). Then, in the case of a traded company, there are investors that think that the company is undervalued (and buy or hold shares), investors that think that the company is overvalued (and sell or not buy shares), and investors that think that the company is fairly valued (and sell or hold shares). The investors that did the last trade, or the rest of the investors that held or did not have shares do not have a common REP (nor common expectations of equity cash flows).

For calculating the REP, we must answer the same question, but thinking in a diversified portfolio of shares, instead in just the shares of a company. In the valuations that I have done in the $21^{\text {st }}$ century I have used REPs between 3.8 and 4\% for Europe and for the U.S. Given the yields of the T-Bonds, I think ${ }^{34}$ that an additional $4 \%$ compensates the additional risk of a diversified portfolio.

\section{Conclusion}

The equity premium (also called market risk premium, equity risk premium, market premium and risk premium), is one of the most important, discussed but elusive parameters in finance. Much of the confusion arises from the fact that the term equity premium is used to designate four different concepts (although many times they are mixed): Historical equity premium (HEP), Expected equity premium (EEP): Required equity premium (REP) and Implied equity premium (IEP).

The four concepts are different. The HEP is equal for all investors, but the REP, the EEP and the IEP are different for different investors. There is no an IEP for the market as a whole: different investors have different IEPs and use different REPs. A unique IEP requires assuming homogeneous expectations for the expected growth (g), but there several pairs (IEP, g) that satisfy current prices.

We show that in the finance and valuation textbooks, there are authors that claim different identities among the four equity premiums defined above: some claim that HEP $=$ EEP $=$ REP; others claim that EEP is smaller than HEP; others claim that there is a unique IEP and that REP = IEP; others "have no official position"; others affirm "that no one knows what the REP is". We claim that "different investors have different REPs" and that "it is impossible to determine the REP for the market as a whole, because it does not exist".

\footnotetext{
${ }^{34}$ And also my clients that are able to answer to that question.
} 


\section{References}

Arzac, E. R. (2005), “Valuation for Mergers, Buyouts, and Restructuring”, New York, John Wiley \& Sons, Inc.

Bodie, Zvi, and R. Merton (2000), “Finance”, New Jersey, Prentice Hall.

Bodie, Z., A. Kane, and A. J. Marcus (2004), "Investments”, $6^{\text {th }}$ edition, New York, McGraw Hill. Previous editions: 1989, 1993, 1996, 1999, 2002.

Bodie, Z., A. Kane, and A. J. Marcus (2003), “Essentials of Investments”, $5^{\text {th }}$ edition, New York, McGraw Hill.

Bostock, P. (2004), “The Equity Premium”, Journal of Portfolio Management 30(2), pp. 104-111.

Brealey, R. A. and S. C. Myers (2003), "Principles of Corporate Finance", $7^{\text {th }}$ edition, New York, McGraw-Hill. Previous editions: 1981, 1984, 1988, 1991, 1996 and 2000.

Brealey, R. A., S. C. Myers and F. Allen (2005), "Principles of Corporate Finance", $8^{\text {th }}$ edition, McGraw-Hill/Irwin.

Brown, S. J., W. N. Goetzmann and S. A. Ross (1995), "Survival", Journal of Finance, July, pp. 853-873.

Bruner, R. F. (2004), “Applied Mergers and Acquisitions, New York, John Wiley \& Sons, Inc.

Copeland, T. E., T. Koller, and J. Murrin (2000), "Valuation: Measuring and Managing the Value of Companies”, $3^{\text {rd }}$ edition, New York, John Wiley \& Sons, Inc. Previous editions: 1990 and 1995.

Copeland, T. E., and J. F. Weston (1988), "Financial Theory and Corporate Policy", $3^{\text {rd }}$ edition, Reading, MA, Addison-Wesley. $1^{\text {st }}$ edition: 1979.

Cowles, A. (1939), “Common Stock Indexes”, Principia Press, Bloomington, Indiana.

Damodaran, Aswath (2006), “Damodaran on Valuation”, $2^{\text {nd }}$ edition, New York, John Wiley and Sons, Inc., $1^{\text {st }}$ edition: 1994.

Damodaran, A. (2001a), “The Dark Side of Valuation”, New York, Prentice-Hall.

Damodaran, A. (2001b), “Corporate Finance: Theory and Practice”, $2^{\text {nd }}$ edition, New York, John Wiley and Sons, Inc.

Damodaran, A. (2001c), "Corporate Finance: Theory and Practice", $2^{\text {nd }}$ international edition, New York, John Wiley and Sons, Inc.

Damodaran, A. (2002), "Investment Valuation", New York, John Wiley and Sons, Inc., $1^{\text {st }}$ edition: 1996.

Dimson, E., P. Marsh and M. Staunton (2006a), "Global Investment Returns Yearbook 2006", ABN AMR0/London Business School.

Dimson, E., P. Marsh and M. Staunton (2006b), "DMS Global Returns data module", Chicago, IL, Ibbotson Associates.

Dimson, E., P. Marsh and M. Staunton (2006c), “The Worldwide Equity Premium: A Smaller Puzzle”, SSRN Working Paper No 891620.

Fernandez, P. (2002), "Valuation Methods and Shareholder Value Creation", Academic Press, San Diego, CA.

Fernandez, P. (2004), “Valoración de Empresas”, $3^{\text {rd }}$ edition, Ediciones Gestión 2000, Spain, $2^{\text {nd }}$ edition: 2001 .

Fernandez, P. (2006), "Equity Premium: Historical, Expected, Required and Implied", IESE Business School Working paper, SSRN No 933070.

Goedhart, M., T. Koller and D. Wessels (2002), “The real cost of Equity”, McKinsey \& Company, No 5, Autumn, pp. 11-15. 
Hawawini, G. and C. Viallet (2002), "Finance for Executives", $2^{\text {nd }}$ edition, South-Western, Thompson Learning.

Ibbotson Associates (2006), "Stocks, Bonds, Bills, and Inflation", Valuation edition, 2006 Yearbook.

Ibbotson, R. (2002), “TIAA-CREF Investment Forum”, June.

Jacquier, E., A. Kane, and A. J. Marcus (2003), “Geometric or Arithmetic Mean: A Reconsideration”, Financial Analysts Journal, Vol. 59, No 6, pp. 46-53.

Jorion, P., and W. N. Goetzmann (1999), "Global stock markets in the twentieth century", Journal of Finance, 54 (June), pp. 953-980.

Koller, T., M. Goedhart and D. Wessels (2005), "Valuation: Measuring and Managing the Value of Companies”, $4^{\text {th }}$ edition, McKinsey \& Company, Inc., John Wiley \& Sons, Inc.

Li, H. and Y. Xu (2002), "Survival Bias and the Equity Premium Puzzle“, Journal of Finance, 57, pp. 1981-1993.

Mas-Colell, A., M. D. Whinston and J. R. Green (1995), "Microeconomic Theory", Oxford University Press.

Miller, M. H. (2000), “The History of Finance: An Eyewitness Account”, Journal of Applied Corporate Finance, Vol. 13, No 2, pp. 8-14.

Penman, S. H. (2003), “Financial Statement Analysis and Security Valuation", $2^{\text {nd }}$ edition, McGraw-Hill. $1^{\text {st }}$ edition in 2001.

Pratt, S. P. (2002), “Cost of Capital: Estimation and Applications”, $2^{\text {nd }}$ edition, John Wiley \& Sons, Inc.

Ross, S. A., R. W. Westerfield and J. F. Jaffe (2005), "Corporate Finance", $7^{\text {th }}$ edition, Homewood, IL, McGraw-Hill/Irwin. Previous editions: 1998, 1993, 1996, 1999 and 2002.

Shiller, R. J. (2000), “Irrational Exuberance”, Princeton University Press, Princeton, New Jersey, 2000.

Siegel, J. (2002), “Stocks for the Long Run", $3^{\text {rd }}$ edition, New York, Irwin. Previous editions: 1994 and 1998.

Smith, E. L. (1926), “Common Stocks as Long Term Investments”.

Stowe, J. D., T. R. Robinson, J. E. Pinto and D. W. McLeavey (2002), “Analysis of Equity investments: Valuation", AIMR (Association for Investment Management and Reasearch).

Van Horne, J. C. (1986), "Fundamentals of Financial Management and Policy", $6^{\text {th }}$ edition, Englewood Cliffs, New Jersey, Prentice-Hall. Previous editions: 1971, 1974, 1977, 1980 and 1983.

Van Horne, J. C. (1992), "Financial Management and Policy", $9^{\text {th }}$ edition, Englewood Cliffs, NJ, Prentice-Hall. Previous editions: 1968, 1971, 1974, 1977, 1980, 1983.

Weston, J. F. and E. F. Brigham (1968), “Essentials of Managerial Finance”, Holt, Rinehart and Winston.

Weston, J. F. and T. E. Copeland (1992), “Managerial Finance”, $9^{\text {th }}$ edition, The Dryden Press.

Weston, J.F., S. Chung and J.A. Siu (1997), "Takeovers, Restructuring and Corporate Governance", $2^{\text {nd }}$ edition, New Jersey, Prentice-Hall.

Weston, J. F., M. L. Mitchel and J. H. Mulherin (2004), “Takeovers, Restructuring, and Corporate Governance", $4^{\text {th }}$ edition, Pearson Education, Prentice Hall. 